\title{
PENILAIAN OTENTIK SEBAGAI SARANA UTAMA IMPLEMENTASI PENDIDIKAN KARAKTER DI SEKOLAH
}

\author{
Yunus Abidin
}

\begin{abstract}
ABSTRAK
Upaya untuk meningkatkan kinerja pendidikan dalam mencetak sumber daya manusia yang unggul dan berkarakter saat ini sedang gencar-gencarnya dilakukan. Salah satu upaya ini adalah dengan mengembangkan satu program pendidikan yang dikenal dengan istilah pendidikan budaya dan karakter bangsa.Pendidikan karakter bertujuan agar siswa mampu menjadi orang yang berkarakter mulia. Usaha pengembangan karakter ini harus dilakukan secara bekesinambungan dalam proses pembelajaran. Secara praktisnya, pembentukan dan pengembangna karakter ini bersifat integratif dengan aktivitas belajar yang dilakukan siswa. Oleh sebab itu, untuk mampu mengukur perkembangan karakter siswa diperlukan sebuah alat yang secara otomatis mampu mengukur aktivitas dan sekaligus menunjukkan karakter siswa. Alat itu adalah penilaian otentik.Penilaian otentik merupakan sebuah bentuk penilaian yang mengukur kinerja nyata yang dimiliki siswa. Kinerja yang dimaksud adalah aktivitas dan hasil aktivitas yang diperoleh siswa selama proses pembelajaran. Berdasarkan pemahaman ini penilaian otentik pada prinsipnya mengukur aktivitas yang dilakukan oleh siswa selama proses pembelajaran berlangsung.
\end{abstract}

\section{Kata Kunci: Pendidikan Karakter, Penilaian Otentik, Penilaian Karakter}

\section{A. Pendahuluan}

Pendidikan di Indonesia saat ini sedang dihadapkan kepada situasi yang yang kurang menguntungkan. Kondisi ini terjadi sejalan dengan semakin banyaknya kenyataan tentang lemahnya karakter bangsa Indonesia yang selama ini diyakini sangat kuat dan teguh memegang sendi-sendi kehidupan yang arif dan bijaksana. Bukti nyata lemahnya karakter bangsa ini dapat kita saksikan di sekitar lingkungan kita. Budaya korupsi, nepotisme, kolusi, hilangnya budaya malu, maraknya penyanjung ketidakjujuran, dan pelemahan potensi anak oleh bangsa kita sendiri semakin kerap kita dengar dan saksikan. Kondisi ini sangat memperihatikan sekaligus menjadi aib bagi pendidikan di Indoensia.

Berbagai kenyataan di atas sangat bertentangan dengan kenyakinan kita selama ini bahwa pendidikan merupakan satu-satunya jalan untuk memanusiakan manusia. Dalam konteks ini, pendidikan dipandang mampu untuk membentuk manusia seutuhnya yang menyadari keberadaan dirinya, lingkungannya dan juga 
Tuhannya. Namun kepercayaan terhadap pandangan ini mungkin saja akan sirna di beberapa dekade ke depan sejalan dengan tudingan terhadap pendidikan yang gagal mencetak anak bangsa yang berbudaya dan berkarakter unggul. Bertemali dengan kondisi ini pendidikan di Indonesia mendapatkan tantangan besar untuk kembali meluruskan berbagai penyimpangan budaya yang saat ini terjadi.

Pembicaraan tentang karakter bangsa, yang secara esensi berhubungan dengan sikap mental negatif bangsa, sebenarnya telah banyak dilakukan para ahli sejak tahun '90-an. Melalui pandangan filosofinya Keontjoroningrat (1990) telah menemukan adanya berbagai sikap mental negatif yang dimiliki sebagian anak bangsa. Beberap sikap mental negatif tersebut di antaranya adalah sikap mental merendahkan mutu dan sikap mental menerabas. Kondisi ini rupanya belum cukup untuk mewakili kondisi bangsa Indonesia dalam kehidupan sehari-hari secara utuh. Kondisi yang lebih mengkhawatirkan adalah tidak adanya lagi sikap bangga terhadap budaya Indonesia. Karena kehilangan rasa bangga budaya Indonesia inilah kemudian banyak manusia Indonesia tidak lagi menghargai budaya luhur warisan bangsa Indonesia. Hal ini menimbulkan sikap mental negatif berikutnya yaitu tuna harga diri.

Berbagai kondisi sikap mental negatif di atas, merupakan problematika bagi pendidikan di Indonesia dan sekaligus menjadi sebuah persoalan budaya dan karakter bangsa yang kini menjadi sorotan tajam masyarakat. Sorotan itu tertuang dalam berbagai tulisan di media cetak, wawancara, dialog, dan gelar wicara di media elektronik. Selain di media massa, para pemuka masyarakat, para ahli, dan para pengamat pendidikan, dan pengamat sosial berbicara mengenai persoalan budaya dan karakter bangsa di berbagai forum seminar, baik pada tingkat lokal, nasional, maupun internasional. Persoalan yang muncul di masyarakat seperti korupsi, kekerasan, kejahatan seksual, perusakan, perkelahian massa, kehidupan ekonomi yang konsumtif, kehidupan politik yang tidak produktif, penggunaan bahasa yang tidak manusiawi, dan sebagainya menjadi topik pembahasan hangat di media massa, seminar, dan di berbagai kesempatan. Berbagai alternatif penyelesaian diajukan seperti peraturan, undang-undang, peningkatan upaya pelaksanaan dan penerapan hukum yang lebih kuat. 
Melihat kondisi ini, wajarlah pendidikan karakter menjadi tema utama yang diusung dunia pendidikan saat ini. Melalui pendidikan karakter diharapkan akan terbentuk perilaku peserta didik yang terpuji sejalan dengan nilai-nilai universal dan tradisi budaya yang luhur. Sejalan dengan tujuan akhir pendidikan karakter tersebut, penulis berkeyakinan bahwa pendidikan memiliki sumbangan besar bagi pembentukan karakter bangsa di masa yang akan datang. Permasalahannya sekarang adalah bagaiman mengimplemtasikan pendidikan karakter dalam konteks pendidikan sehari-hari di berbagai jenjang pendidikan yang ada di Indonesia?

\section{B. Beberapa Asumsi Pendidikan Karakter yang Salah Arah}

Upaya untuk meningkatkan kinerja pendidikan dalam mencetak sumber daya manusia yang unggul dan berkarakter saat ini sedang gencar-gencarnya dilakukan. Salah satu upaya ini adalah dengan mengembangkan satu program pendidikan yang dikenal dengan istilah pendidikan budaya dan karakter bangsa. Pendidikan budaya dan karakter bangsa dimaknai sebagai pendidikan yang mengembangkan nilai-nilai budaya dan karakter bangsa pada diri peserta didik sehingga mereka memiliki nilai dan karakter sebagai karakter dirinya, menerapkan nilai-nilai tersebut dalam kehidupan dirinya, sebagai anggota masyarakat, dan warganegara yang religius, nasionalis, produktif dan kreatif.

Sejalan dengan definisi di atas, fungsi pendidikan budaya dan karakter bangsa adalah sebagai berikut.

1. pengembangan: pengembangan potensi peserta didik untuk menjadi pribadi berperilaku baik; ini bagi peserta didik yang telah memiliki sikap dan perilaku yang mencerminkan budaya dan karakter bangsa;

2. perbaikan: memperkuat kiprah pendidikan nasional untuk bertanggung jawab dalam pengembangan potensi peserta didik yang lebih bermartabat; dan

3. penyaring: untuk menyaring budaya bangsa sendiri dan budaya bangsa lain yang tidak sesuai dengan nilai-nilai budaya dan karakter bangsa yang bermartabat. (Depdiknas, 2010: 7) 
Bertemali dengan fungsinya di atas, tujuan pendidikan budaya dan karakter bangsa adalah sebagai berikut.

1. mengembangkan potensi kalbu/nurani/afektif peserta didik sebagai manusia dan warganegara yang memiliki nilai-nilai budaya dan karakter bangsa;

2. mengembangkan kebiasaan dan perilaku peserta didik yang terpuji dan sejalan dengan nilai-nilai universal dan tradisi budaya bangsa yang religius;

3. menanamkan jiwa kepemimpinan dan tanggung jawab peserta didik sebagai generasi penerus bangsa;

4. mengembangkan kemampuan peserta didik menjadi manusia yang mandiri, kreatif, berwawasan kebangsaan; dan

5. mengembangkan lingkungan kehidupan sekolah sebagai lingkungan belajar yang aman, jujur, penuh kreativitas dan persahabatan, serta dengan rasa kebangsaan yang tinggi dan penuh kekuatan (dignity). (Depdiknas, 2010: 7)

Dalam pelaksanaannya, ada 18 nilai yang dianggap paling sesuai dengan nilai-nilai luhur bangsa Indonesia. Garis-garis besar pendidikan karakter sebagai mana diungkapkan di atas tentu saja akhirnya menibulkan berbagai persepsi yang sangat beragam. Hal ini sejalan dengan kenyataan bahwa panduan yang dibuat depdiknas pun belum mampu memberikan pedoman pasti tentang bagaimana melaksanakan pendidikan karakter di sekolah. Dalam tulisan ini perlu kiranya kita pahami beberapa pandangan keliru tentang implementasi pendidikan karakter di sekolah.

\section{Pendidikan Karakter adalah materi ajar yang bersifat penguasaan}

Salah pandangan yang sangat salah dalam menafsirkan penerapan pendidikan karakter adalah pandangan bahwa pendidikan karakter adalah suatu bidang studi atau materi ajar yang harus dikuasai siswa. Pendangan ini melihat bahwa pendidikan karakter harus dijadikan sebuah mata pelajaran baru di sekolah (lihat misalnya pendidikan lingkungan hidup). Konsepsi demikian jelaslah merupakan konsepsi yang akan memburuk pendidikan di Indonesia yang selama ini saja sudah dikategorikan sebagai pendidikan dengan mata pelajaran terbayak di dunia (bandingkan dengan Jepang, Singapura, Malaysia). 
Karakter sebagai suatu moral excellence dibangun di atas berbagia kebajikan (virtues) yang pada gilirannya hanya memiliki makna ketika dilandasi atas nilai-nilai yang berlaku dalam budaya bangsa. Berbeda dari materi ajar yang bersifat mastery, sebagaimana halnya suatu performance content suatu kompetensi, materi Pendidikan Budaya dan Karakter Bangsa bersifat developmental. Perbedaan hakekat kedua kelompok materi tersebut menghendaki perbedaan perlakuan dalam proses pendidikan. Materi pendidikan yang bersifat developmental menghendaki proses pendidikan yang cukup panjang dan bersifat saling menguat (reinforce) antara kegiatan belajar dengan kegiatan belajar lainnya, antara proses belajar di kelas dengan kegiatan kurikuler di sekolah dan di luar sekolah.

Di samping persamaan dalam kelompok, materi belajar ranah pengetahuan (cognitive) yang dalam satu kelompok developmental dengan nilai, antara keduanya terdapat perbedaan yang mendasar dalam perencanaan pada dokumen kurikulum (KTSP), silabus, RPP, dan proses belajar. Materi belajar ranah pengetahuan dapat dijadikan pokok bahasan sedangkan materi nilai dalam Pendidikan Budaya dan Karakter Bangsa tidak dapat dijadikan pokok bahasan karena mengandung resiko akan menjadi materi yang bersifat kognitif. Oleh karena itu, dalam pengembangan materi Pendidikan Budaya dan Karakter Bangsa sikap menyukai, ingin memiliki, dan mau menjadikan nilai-nilai tersebut sebagai dasar bagi tindakan dalam perilaku kehidupan peserta didik sehari-hari merupakan persyaratan awal yang mutlak untuk keberhasilan Pendidikan Budaya dan Karakter Bangsa.

Proses Pembelajaran Pendidikan Budaya dan Karakter Bangsa dilaksanakan melalui proses belajar aktif. Sesuai dengan prinsip pengembangan nilai harus dilakukan secara aktif oleh peserta didik (dirinya subyek yang akan menerima, menjadikan nilai sebagai miliknya dan menjadikan nilai-nilai yang sudah dipelajarinya sebagai dasar dalam setiap tindakan) maka posisi peserta didik sebagai subyek yang aktif dalam belajar adalah prinsip utama belajar aktif. Oleh karena itu, keduanya saling memerlukan. 


\section{Pendidikan karakter adalah mengembalikan P4}

Pandangan kedua yang keliru menafsirkan penerapan pendidikan karakter adalah bahwa pendidikan karakter identik dengan pendidikan P4 pada zaman orde baru. Pandangan ini terutama muncul pada beberapa tokoh pendidikan katakter di Indonesia yang masih sangat kental dengan kepemimpinan ala militer yang pernah diterapkan pada zaman oder baru. Persepsi ini tentu saja akan berdampak pada kenyataan bahwa kita merupakan orang yang mengais kebajikan pada ludah yang pernah kita tumpahkan. Sungguh pandangan ini jelas-jelas tidak berkarater sama sekali.

Dalam persepsi ini, pendidikan karakter merupakan sebuah pendidikan yang diarahkan agar peserta didik menghafal sejumlah ayat-ayat tertentu agar terkesan berkarakter. Penghafan ini diharapkan akan mampu menjadi jiwa dalam kehidupan sehari-hari. Tentu saja pandangan demikian bukanlah pandangan yang benar sebab penghapalan hanya bersifat kognitif tingkat rendah yang jauh dari perilaku yang sesungguhnya.

Salah satu hal yang paling penulis takutkan ketika muncul persepsi ini adalah bahwa jangan-jangan pendidikan karakter hanya akan menjadi dogma bagi siswa. Dalam hal ini siswa didogma untuk berada dalam sebuah keseragaman dalam kondisi yang sangat majemuk. Dogmatisasi semacam ini akan menyeret pada kekerdilan bangsa ditengah luas dan cepatnya perkembangan ilmu pengetahuan. Bertemali dengan kenyataan ini, semoga pandangan ini tidak menjadi pandangan dominan ditengah implementasi pendidikan karakter di Indonesia yang kalau diibaratkan sangat memerlukan air hujan dalam kemarau panjang dan gersang.

\section{Pendidikan karakter adalah pendidikan moral, nilai, dan agama}

Pandangan ketiga yang sering muncul dan terkesan paling dominan adalah bahwa pendidikan karakter adalah pendidikan agama yang dituangkan dalam seluruh mata pelajaran. Pandangan ini memang masih dapat dikatakan logis, karena sendi kehidupan manusia senantiasa harus berdasarkan pada agama dan kenyakinan yang dianut. Namun demikian, penafsiran pendidikan karakter 
sebagai pendidikan agama yang dituangkan dalam berbagai mata pelajaran adalah sebuah pandangan yang sangat sempit.

Berkembangnya paradigma ini didasarkan atas asumsi bahwa pendidikan karakter adalah pendidikan tentang ahlak mulia. Berbicara ahlak mulia tentu saja berbicara tentang agama. Oleh karenanya, pendidikan karakter cukup dilakukan melalui pendidikan agama bukan pendidikan yang berlandasarkan agama. Jika pandangan ini kemudian menjadi pandangan yang paling dominan dalam pelaksanaan pendidikan karakter di Indonesia, penulis masih menyimpan seribu pertanyaan yang salah satunya yakni bukankah kebrok-brokan bangsa ini lahir ditengan maraknya siar berbagai agama?Lantas, maukah kita mengecap bahwa pelaksanaan pendidikan agama baik sekolah maupun di luar sekolah yang selama ini kita lakukan telah gagal? Tentu pandanga ini sangat sarkasme dan akan mendangkan pertentangan panjang berikut. Atas dasar itu, penulis berpendapat pendidikan karakter bukan pendidikan agama tetapi pendidikan yang dilandasi agama.

\section{Pendidikan Karakter adalah Projek}

Pandangan keempat ini adalah pandangan yang saat ini mulai berkecambah pada pemikiran beberapa pengamat pendidikan di Indonesia. Tentu saja ini pandangan ini sebenarnya merupakan pandangan yang sangat fesimistis, yang memandang segala sesuatu berdasarkan pola pikir negatif. Lantas, mengapa pandangan ini muncul di tengah hingar-bingarnya pendidikan karakter di Indonesia?

Kemunculan pandangan ini tentu saja bukan tanpa dasar. Beberapa fakta logis tentang penerapan pendidikan karakter memang bertemali dengan beberapa fakta yang telah terjadi dalam sejarah pendidikan di Indonesia. Salah satu fakta yang masih sangat kental dalam ingatan kita adalah pendidikan kecakapan hidup yang penah bergaung dalam konteks pendidikan Indonesia pada tahun 2004. Tentu kita masih ingat, sejalan dengan diberlakukannya KBK, pendidikan kecakapan hidup menjadi muatan yang kental dalam implementasi KBK. Hal ini ditandai dengan seminar, penataran, pelucuran berbagai buku tentang $\mathrm{PKH}$, dan implementasi PKH di sekolah yang diawasi secara ketat. Dalam kondisi tersebut, 
guru harus mampu menyusun standar kecakapan yang harus miliki siswa yang selanjutnya guru melakukan penilaian terhadap masing-masing siswa dalam kelas yang dibuktikan dengan sistem dokumentasi yang rumit dan akhirnya membuat guru menjadi lelah dan meninggal, secara pelan tetapi pasti, penilaian kecakapan hidup.

Lantas apa kaitanya dengan pendidikan karakter. Menilik pola acuan pengembangan pendidikan karakter yang dibuat Kemendiknas, upaya ke arah penerapan pendidikan karakter yang dinilai secara ketat sebagaimana layaknya pendidikan kecakapan hidup telah muncul. Kondisi penilaian ini akan membuat semakin beratnya beban administrasi yang harus ditanggung guru. Bayangkan saja, saat ini saja guru telah harus berupaya membuat RPP karakter yang nantinya harus pula ditambah dengan penilaian karakter untuk masing-masing siswa. Melihat kondisi ini mungkinkan pendidikan karakter akan berjalan? Menilik sejarah, penulis yakin pendidikan karakter tidak akan bertahan lama.

\section{Meluruskan Arah Implementasi Pendidikan Karakter}

Berbagai pandangan tentang pendidikan karakter sebagai mana dikemukakan di atas, tentu saja harus kita buang jauh-jauh dalam pemikiran kita sebagai seorang pendidikan dan ilmuwan. Lantas bagaimanakah penerapan pendidikan karakter yang sesunggunya? Dalam pandangan penulis, pendidikan karakter merupakan bagian yang tidak dapat dipisahkan dari kegiatan pembelajaran aktif. Jadi, pendidikan karakter adalah proses pembelajaran itu sendiri.

Pemahaman tentang pendidikan karakter adalah proses pembelajaran memang sepertinya sangat tidak ilmiah. Namun dalam pandangan penulis, pemaknaan yang demikian adalah pemaknaan yang paling mungkin bagi penerapan pendidikan karakter dalam proses pembelajaran sehari-hari. Pendidikan karakter adalah pengejawatahan pembelajaran aktif dalam proses belajar mengajar. Lalu bagaimana mencari benang merah antara pendidikan karakter dengan proses pembelajaran? 
Guna menjawab pertanyaan di atas, hal yang pertama harus kita lakukan adalah memaknai istilah pembelajaran secara benar. Pembelajaran adalah usaha yang dilakukan guru agar siswa belajar. Dalam pengertian ini, siswa adalah individu yang melakukan berbagai aktivitas belajar guna membangun dan mengembangkan pengetahuan sendiri. Kata aktivitas, dalam padangan penulis, merupakan kata kunci dari proses pembelajaran. Aktivitas yang dimaksud adalah aktivitas siswa bukan aktivitas guru. Jika pembelajaran diartikan sebagai segala bentuk aktivitas yang dilakukan siswa, aktivitas tersebutlah yang selanjutnya harus mengarah pada beberapa nilai yang terkandung dalam pendidikan karakter. Misal, dalam pembelajaran IPA, seorang anak diharuskan menguasai kompetensi tentang benda hidup dan benda mati. Tentu saja penguasaan ini akan sangat mudah dilakukan siswa ketika guru langsung membacakan ciri-ciri benda hidup dan benda mati serta menyebutkan contoh-contohnya. Namun di mana pembentukan karakter terhadap siswa? Tentu saja dalam kasus seperti ini tidak akan ada usaha pengembangan karakter terhadap siswa.

Masih bertemali dengan contoh di atas, seandainya seorang guru mengajarkan materi yang sama lantas mengembangkan pembelajaran aktif dengan model kontekstual misalnya, tentu saja guru tersebut akan menyuruh siswa melakukan kegiatan eksplorasi untuk menemukan contoh dan ciri-ciri benda hidup dan benda mati yang ada di sekitar lingkungan anak. Kegiatan mengeksplorasi yang dilakukan anak ini adalah wujud aktivitas yang sebenarnya mengadung muata karakter. Siswa yang mampu menemukan sepuluh contoh benda hidup dan benda mati di lingkungan sekolah misalnya, ia telah beraktivitas melakukan pengamatan secara cermat, teliti, dan lengkap. Proses pengamatan sebagai bentuk aktivitas belajar inilah sebenarnya sarana pembentukan karakter. Pada siswa yang mampu menyelesaikan tugasnya ini kita dapat katakan bahwa dia adalah anak yang bertanggung jawab, memiliki rasa ingin tahu, dan mampu bekerja keras. Bukankah ini nilai dari karakter yang dimaksudkan dalam pendidikan budaya dan karakter bangsa yang saat ini sedang digemborgemborkan? Seandainya lagi, dalam proses pengumpulan datanya dilakukan berdasarkan penugasan individu untuk melengkapi tugas kelompok, bukankah ini 
juga karakter kerja sama yang saling berketergatungan positif, bukankah ini sarana untuk membentuk kemandirian dan kedemokratisan?

Menilik contoh sederhana di atas, penerapan pendidikan karakter dalam proses pembelajaran bukanlah beban berat. Yang berat adalah mengubah kebiasaan kita dalam mengajar. Bukankah kita saat ini lebih disibukkan dengan membuat RRP dibanding mengembangkan model mengajar kreatif? Bukankah kita sangat cemas, atau senang karena tidak perlu mengajar, ketika suara kita parau sebab kita mengajar hanya dengan menggunakan metode ceramah atau diskusi yang kadaluarsa?

Sebagai sebuah tawaran konseptual, penulis berkeyakinan bahwa pendidikan karakter bukan pendidikan yang akan memberatkan beban guru melainkan sebuah tantangan bagi guru untuk melakukan pembelajaran secara benar, yakni menekankan proses pembelajaran sebagai aktivitas anak secara nyata dalam membangun pengetahuan. Jikalau demikian, apa langkah utama yang harus dilakukan guru akan pendidikan karakter dapat diimplementasikan di sekolah? Langkah pertama adalah menyakinkan diri bahwa pembelajaran adalah serangkaian aktivitas yang harus dilakukan siswa. Melalui aktivitas tersebutlah pendidikan karakter dilakukan. Pertanyaannya sekarang, bagaimana menilai perkembangan karakter anak karena penilaian ini diwajibkan pihak pembuat kebijakan? Jawabanya adalah mudah lakukan kegiatan penilaian otentik sebagaimana diwajibkan dalam KTSP, sebab melalui penilaian otentik inilah sebenarnya kita dapat menilai ketercapaian pembelajaran sekaligus menilai perkembangan karakter anak.

Bertemali dengan konsep di atas, ada beberapa hal yang harus kita luruskan dengan pemahaman tentang penilaian proses atau penilaian otentik. Beberapa paham ini perlu dikemukakan sebelum kita memahami apa sebetulnya penilaian proses atau penilaian otentik tersebut.

1. Penilaian otentik bukan penilaian yang dilakukan untuk mengukur sesuatu yang tidak bisa diukur, misalnya kesungguh-sungguhan, keantusiasan, perhatian, dan beberapa indikator penilaian proses yang salah lainnya yang selama ini bekembang. 
2. Buang jauh-jauh pandangan atas paradigma yang selama ini berkembang bahwa penilaian formatif adalah ulangan harian. Penilaian formatif adalah penilaian otentik itu sediri yakni penilaian yang menilai apa yang benar-benar sudah dikuasai dan tidak dikuasai siswa selama prose pembelajaran bukan pada akhir bab atau pokok bahasan tertentu.

3. Buang jauh-jauh paradigma bahwa nilai sebuah ulangan merupakan umpan balik bagi siswa dan proses pembelajaran. Umpan balik/ sapu balik (wash back) yang benar berasal dari penilaian yang dilakukan terhadap siswa selama proses pembelajaran atau penilaian otentik terhadap satu indikator tertentu. Misalnya jangan mengatakan dengan memberi tahu bahwa kemampuan mengarang kalian jelek sebagai umpan balik, melainkan sampaikan kemampuan Anda tentang menemukan dan mengorganisikan ide masih kurang. Atas dasar kekurangan inilah akan akan memperbaiki kemampuannya mengarangnya.

4. Jangan lakukan pemberian PR bagi anak terhadap konsep yang belum dikuasai anak. Hal ini hanya akan semakin menyesatkan siswa. Pemberian PR hanya boleh dilakukan terhadap konsep yang telah dikuasi siswa. Dengan demikian PR antara anak tidak akan seragam karena akan bergantung pada kemampuan anak.

5. Buang jauh-jauh keyakinan kita bahwa penilaian otentik tidak bisa dilakukan sebelum kita benar-benar mencoba dan menyerah. Jangan berpikir bahwa penilaian otentik mementingkan proses daripada hasil, sebab penilaian otentik mementingkan keduanya.

\section{Penilaian Otentik sebagai Sarana Utama Pelaksanaan Pendidikan Karakter di Sekolah}

\section{Makna Penilaian Otentik}

Model penilaian otentik (authentic assessment) dewasa ini banyak dibicarakan di dunia pendidikan karena model ini direkomendasikan, atau bahkan harus ditekankan, penggunaannya dalam kegiatan menilai basil belajar pembelajar. Salah satu permasalahan yang muncul adalah belum tentu semua guru/ dosen memahami 
konsep dan pelaksanaan penilaian otentik. Jika sebuah konsep belum terpahami, bagaimana mungkin kita mau mempergunakannya untuk keperluan praktis pada kegiatan pembelajaran? Mungkin saja orang menyangka atau mengatakan telah mempergunakan penilaian otentik untuk menilai hasil belajar siswa, tetapi pada kenyataannya tidak demikian.

Penilaian Otentikadalah proses pengumpulan berbagai data yang bisa memberikan gambaran perkembangan belajar siswa. Gambaran perkembangan belajar siswa perlu diketahui oleh guru agar bisa memastikan bahwa siswa mengalami proses pembelajaran dengan benar. Apabila data yang dikumpulkan guru mengidentifikasikan bahwa siswa mengalami kemacetan dalam belajar, guru segera bisa mengambil tindakan yang tepat agar siswa terbebas dari kemacetan belajar. Karena gambaran tentang kemajuan belajar itu diperlukan di sepanjang proses pembelajaran, penilaian ini tidak dilakukan di akhir periode saja (akhir semester). Kegiatan penilaian dilakukan bersamaan dengan kegiatan pembelajaran. (Abidin, 2011: 10)

Penilaian otentik mementingkan penilaian proses dan hasil sekaligus. Dengan demikian, seluruh tampilan siswa dalam rangkaian kegiatan pembelajaran dapat dinilai secara objektif, apa adanya, dan tidak semata-mata hanya berdasarkan hasil akhir (produk) saja. Lagi pula amat banyak kinerja siswa yang ditampilkan selama berlangsungnya kegiatan pembelajaran sehingga penilaiannya haruslah dilakukan selama dan sejalan dengan berlangsungnya kegiatan proses pembelajaran. Jika dilihat dari sudut pandang teori Bloom-sebuah model yang dijadikan acuan pengembangan penilaian dalam beberapa kurikulum di Indonesia sebelum ini-penilaian haruslah mencakup ranah kognitif, afektif, dan psikomotorik.

Cara penilaian juga bermacam-macam, dapat menggunakan model nontes dan tes sekaligus, serta dapat dilakukan kapan saja bersamaan dengan kegiatan pembelajaran. Namun, semuanya harus tetap terencana secara baik. Penilaian yang dilakukan lewat berbagai cara atau model, menyangkut berbagai ranah, serta meliputi proses dan produk inilah yang kemudian disebut sebagai penilaian otentik. Otentik dapat berarti dan sekaligus menjamin objektif, nyata, konkret, benar-benar hasil tampilan siswa, serta akurat dan bermakna. 
Menurut Jonathan Mueller assessment otentik adalah suatu penilaian belajar yang merujuk pada situasi atau konteks dunia "nyata" yang memerlukan berbagai macam pendekatan untuk memecahkan masalah yang memberikan kemungkinan bahwa satu masalah bisa mempunyai lebih dari satu macam pemecahan. Dengan kata lain, asesmen otentik memonitor dan mengukur kemampuan siswa dalam bermacam-macam kemungkinan pemecahan masalah yang dihadapi dalam situasi atau konteks dunia nyata dan dalam suatu proses pembelajaran nyata. Dalam suatu proses pembelajaran, penilaian otentik mengukur, memonitor, dan menilai semua aspek hasil belajar (yang tercakup dalam domain kognitif, afektif, dan psikomotor), baik yang tampak sebagai hasil akhir dari suatu proses pembelajaran, maupun berupa perubahan dan perkembangan aktifitas, dan perolehan belajar selama proses pembelajaran didalam kelas maupun siluar kelas.

Menurut (Hart, 1994), asesmen otentik yaitu asesmen yang melibatkan siswa didalam tugas-tugas otentik yang bermanfaat, penting, dan bermakna. Hal senada juga dijelaskan oleh David W. Johnson dan Roger T. Johnson (2002) bahwa otentik asesmen meminta siswa untuk mendemonstrasikan keterampilan atau prosedur dalam konteks dunia nyata.

"Authentic assessment requires students to demonstrate desired skill or procedure in real-life contexs. To conduct an authentic assessment in science, for example: you may assign students to research teams that work on a cure for cancer bay (1) conducting an experiment, (2) writing a lab report summarizing results, (3) writing in journal article, and making oral presentation".

Penilaian otentik juga disebut dengan penilaian alternatif. Pelaksanaan penilaian otentik tidak lagi menggunakan format-format peniaian tradisional (multiple-choice, matching, true-false, dan paper and pencil test), tetapi menggunakan format yang memungkinkan siswa untuk menyelesaikan suatu tugas atau mendemonstrasikan suatu performasi dalam memecahkan suatu masalah. Format penilaian ini dapat berupa: (a) tes yang menghadirkan benda atau kejadian asli ke hadapan siswa (hands-on penilaian), (b) tugas (tugas keterampilan, tugas investigasi sederhana dan tugas investigasi terintegrasi), (c) format rekaman kegiatan belajar siswa (misalnya: portofolio, interview, daftar cek, dsb. 
Pada hakikatnya, kegiatan penilaian yang dilakukan tidak semata-mata untuk menilai hasil belajar siswa saja, melainkan juga berbagai factor yang lain, antara lain kegiatan pengajaran yang dilakukan itu sendiri. Artinya, berdasarkan informasi yang diperoleh dapat pula dipergunakan sebagai umpan baik penilaian terhadap kegiatan yang dilakukan (Nurgiyantoro, 2011: 4)

O’Malley dan Pierce (1996: 4) mendefinisikan authentic assessmentsebagai berikut:

"Authentic assessment is an evaluation process that involves multiple forms of performance measurement reflecting the student's learning, achievement, motivation, and attitudes on instructionally-relevant activities. Example of authentic assessment techniques include performance assessment, portofolio, and self-assessment".

Asesmen otentik juga merupakan sebutan yang digunakan untuk menggambarkan tugas-tugas yang riil yang dibutuhkan siswa-siswa untuk dilaksanakan dalam menghasilkan pengetahuan mereproduksi informasi. Sebagai contoh, dalam pembelajaran matematika seorang siswa belumlah dikatakan belajar secara bermakna bilamana dia belum mampu menggunakan rumus-rumus matematis yang dipelajarinya untuk menyelesaikan suatu masalah sehari-hari, seperti ketika kita berbelanja. Oleh karena itu, dalam pembelajaran sangat perlu dilakukan asesmen otentik untuk menjamin pembentukan kompetensi riil pada siswa.

Beberapa pembaharuan yang tampak pada penilaian otentik adalah(a) melibatkan siswa dalam tugas yang penting, menarik, berfaedah dan relevan dengan kehidupan nyata siswa;(b) tampak dan terasa sebagai kegiatan belajar, bukan tes tradisional;(c) melibatkan keterampilan berpikir tingkat tinggi dan mencakup pengetahuan yang luas, (d) menyadarkan siswa tentang apa yang harus dikerjakannya akan dinilai;(e) merupakan alat penilaian dengan latar standar (standar setting), bukan alat penilaian yang distandarisasikan;(f) berpusat pada siswa (student centered) bukan berpusat pada guru (teacher centered); dan (g) dapat menilai siswa yang berbeda kemampuan, gaya belajar, dan latar belakang kulturnya.

Penilaian otentik menekankan kemampuan pembelajar untuk mendemonstrasikan pengetahuan yang dimiliki secara nyata dan bermakna. Kegiatan 
penilaian tidak sekedar menanyakan atau menyadap pengetahuan yang telah diketahui pembelajar, melainkan kinerja secara nyata dari pengetahuan yang telah dikuasai. Sebagaimana dinyatakan Mueller (2008) penilaian otentik merupakan: a form of assessment in which students are asked to perform real-world tasks that demonstrate meaningful application of essential knowledge and skills. Jadi, penilaian otentik merupakan suatu bentuk tugas yang menghendaki pembelajar untuk menunjukkan kinerja di dunia nyata secara bermakna yang merupakan penerapan esensi pengetahuan dan keterampilan. Menurut Stiggins (Mueller, 2008), penilaian otentik merupakan penilaian kinerja (perfomansi) yang meminta pembelajar untuk mendemonstrasikan keterampilan dan kompetensi tertentu yang merupakan penerapan pengetahuan yang dikuasainya.Hal yang serupa dikemukakan oleh Hiebert, Valencia, \& Afferbach (1994, http: / /www.eduplace.com/,) yang menyatakan bahwa penilaian otentik merupakan penilaian terhadap tugas-tugas yang menyerupai kegiatan membaca dan menulis sebagaimana halnya di dunia nyata dan di sekolah. Tujuan penilaian itu adalah untuk mengukur berbagai keterampilan dalam berbagai konteks yang mencerminkan situasi di dunia nyata di mana keterampilan-keterampilan tersebut digunakan. Misalnya, penugasan kepada pembelajar untuk membaca berbagai teks aktual-realistik, menulis topik-topik tertentu sebagaimana halnya di kehidupan nyata, dan berpartisipasi konkret dalam diskusi atau bedah buku, menulis untuk jurnal, stoat, atau mengedit tulisan sampai siap cetak. Dalam kegiatan itu, baik materi pembelajaran maupun penilaiarmya terlihat atau bahkan memang alamiah.

Jadi, penilaian model ini menekankan pada pengukuran kinerja, doing something, melakukan sesuatu yang merupakan penerapan dari ilmu pengetahuan yang telah dikuasai secara teoretis. Penilaian otentik lebih menuntut pembelajar mendemonstrasikan pengetahuan, keterampilan, dan strategi dengan mengkreasikan jawaban atau produk. Siswa tidak sekedar diminta merespon jawaban seperti dalam tes tradisional, melainkan dituntut untuk mampu mengkreasikan dan menghasilkan jawaban yang dilatarbelakangi oleh pengetahuan teoretis. Dalam penilaian kemampuan bersastra misalnya, pembelajar mampu menganalisis karakter tokoh dalam sebuah fiksi, mempertanggungjawabkan kinerjanya tersebut secara argumentatif, membuat resensi teks kesastraan, dan lain-lain. 
Masalah kinerja, performansi, demonstrasi, atau apalah istilahnya, tentulah dalam pengertian sesuai dengan karakteristik masing-masing mata pelajararn. Tiap mata pelajaran tentu memiliki kriteria kinerja yang belum tentu sama dengan mata-mata pelajaran yang lain. Kinerja hasil pembelajaran bahasa tentu. tidak sama dengan hasil pembelajaran matematika, teknik otomotif, tata busana, seni musik, dan lain-lain. Namun, pada prinsipnya semua mata pelajaran itu haruslah melaksanakan penilaian dan salah satunya dengan model penilaian otentik. Walau tiap mata pelajaran berbeda karakteristik, balk yang termasuk kategori ilmu-ilmu eksakta maupun sosial dan humaniora, kesemuanya tampaknya dapat menerapkan model penilaian.

Asesmen otentik adalah Asesmen adalah suatu proses pengumpulan data siswa baik yang dilakukan selama proses pembelajaran, maupun terhadap hasil belajar. Data-data yang dikumpulkan tersebut selanjutnya dianalisis dan hasil analisis tersebut berfungsi sebagai balikan terhadap pembelajaran, maupun sebagai bahan pengambilan keputusan terhadap status siswa (formtif dan sumatif). Wiggins (1993) mengatakan bahwa asesmen otentik merupakan:

"Engaging and worthy problems or questions of importance, in which students must use knowledge to fashion performances effectively and creatively. The tasks are either replicas of or analogous to the kinds of problems faced by adult citizens and consumers or professionals in the field."

Dengan pengertian di atas, sangat jelas bahwa asesmen otentik sangat terkait dengan upaya pencapaian kompetensi. Kompetensi adalah pengetahuan, keterampilan, dan sikap yang terunjukkerjakan dalam kebiasaan berfikir dan bertindak dalam suatu persoalan yang dihadapi. Ciri utama kompetensi adalah "able to do , yaitu siswa dapat melakukan sesuatu berdasarkan pengetahuan dan keterampilan yang dipelajarinya. Melalui asesmen otentik, hal tersebut sangat mungkin untuk diterjadikan. Oleh karena itu, KTSP dengan jelas menyarankan guru untuk mengurangi menggunakan tes-tes objektif, utamanya untuk asesmen yang bersifat formatif.

Asesmen otentik adalah asesmen yang gayut dengan ciri peserta didik aktif membangun pengetahuan, hingga terbentuk kompetensi seperti yang ditetapkan dalam SKL, SK, KD, dan indikator. Tes-tes objektif bukan asesmen 
otentik karena jenis tes tersebut merupakan imposed target by the tester with only one single answer. Tes objektif tidak memberi kesempatan peserta didik menemukan jawaban atas persoalan yang dihadapi dengan caranya sendiri, tetapi dipaksa dengan hanya sedikit pilihan tanpa boleh mengambil pilihan diluar pilihan yang diberikan.

Secara garis besar, asesmen otentik memiliki sifat-sifat (1) berbasis kompetensi yaitu asesmen yang mampu memantau kompetensi seseorang. Asesmen otentik pada dasarnya adalah asesmen kinerja, yaitu suatu unjuk kerja yang ditunjukkan sebagai akibat dari suatu proses belajar yang komprehensif. Kompetensi adalah atribut individu peserta didik.Olehkarena itu, asesmen berbasis kompetensi bersifat (2) individual. Kompetensi tidak dapat disamaratakan pada semua orang, tetapi bersifat personal. Karena itu, asesmen harus dapat mengungkapkan seoptimal mungkin kelebihan setiap individu, dan juga kekurangannya (untuk bisa dilakukan perbaikan); (3) berpusat pada peserta didik karena direncanakan, dilakukan, dan dinilai oleh guru dengan melibatkan secara optimal peserta didik sendiri; Asesmen otentik bersifat tak terstruktur dan open-ended, dalam arti, percepatan penyelesaian tugas-tugas otentik tidak bersifat uniformed dan klasikal, juga kinerja yang dihasilkan tidak harus sama antar individu di suatu kelompok. Untuk memastikan bahwa yang diases tersebut benar-benar adalah kompetensi riil individu (peserta didik) tersebut, maka asesmen harus dilakukan secara (4) otentik (nyata, riil seperti kehidupan sehari-hari) dan sesuai dengan proses pembelajaran yang dilakukan, sehingga asesmen otentik berlangsung secara (5) terintegrasi dengan proses pembelajaran. Asesmen otentik bersifat (6) on-going atau berkelanjutan, oleh karena itu asesmen harus dilakukan secara langsung pada saat proses belajar mengajar berlangsung, dimana dapat terpantau roses dan produk belajar. Dengan demikian, asesmen otentik memiliki sifat berpusat pada peserta didik, terintegrasi dengan pembelajaran, otentik, berkelanjutan, dan individual (Marhaeni, 2005). Sifat asesmen otentik yang komprehensif juga dapat membentuk unsurunsur metakognisi dalam diri peserta didik seperti risk-taking, kreatif, 
mengembangkan kemampuan berfikir tingkat tinggi dan divergen, tanggungjawab terhadap tugas dan karya, dan rasa kepemilikan (ownership).

\section{Penilaian Otentik versus Penilaian Tradisional}

Penilaian otentik sebenarnya telah lama dikenal di dunia pendidikan, tetapi baru naik daun di era KTSP. Sebenarnya, bentuk-bentuk penilaian otentik bukan merupakan barang asing bagi para pendidik di Indonesia karena sebagian (baik sebagai pelaku maupun pemilihan bentuk) telah melakukan penilaian model itu. Hanya memang pada umumnya kita lebih akrab dengan penilaian model tradisional. Penilaian tradisional dalam kaitan ini dilihatsebagai penilaian yang lebih banyak menyadap pengetahuan yang telah dikuasai siswa sebagai hasil belajar yang pada umumnya ditagih lewat bentukbentuk tes objektif. Di pihak lain, penilaian otentik lebih menekankan pada pemberian tugas yang menuntut pembelajar menampilkan, mempraktikkan, atau mendemonstrasikan basil pembelajarannya di dunia nyata secara bermakna yang mencerminkan penguasaan pengetahuan dan keterampilan dalam suatu mata pelajaran. Singkatnya, penilaian tradisional lebih menekankan tagihan penguasaan pengetahuan, sedang penilaian otentik kinerja atau tampilan yang mencerminkan penguasaan pengetahuan dan keterampilan.

Secara lebih konkret Mueller (2008) menunjukkan adanya persamaan dan perbedaan antara penilaian tradisional dan penilaian otentik. Penilaian tradisional antara lain memiliki karakteristik sebagai berikut.

a. Misi sekolah adalah mengembangkan warga negara yang produktif.

b. Untuk menjadi warga negara produktif, seseorang harus menguasai disiplin keilmuan dan keterampilan tertentu.

c. Maka, sekolah mesti mengajarkan siswa disiplin keilmuan dan keterampilan tersebut.

d. Untuk mengukur keberhasilan pembelajaran, guru harus mengetes siswa untuk mengetahui tingkat penguasaan keilmuan dan keterampilan itu.

e. The curriculum drives assessment; thebody of knowledge is determined first.

Di pihak lain, penilaian otentik memiliki karakteristik sebagai berikut.

a. Misi sekolah adalah mengembangkan warga negara yang produktif. 
b. Untuk menjadi warga negara produktif, seseorang harus mampu menunjukkan penguasaan melakukansesuatu secara bermakna dalam dunia nyata.

c. Maka, sekolah mesti mengembangkan siswa untuk dapat mendemonstrasikan kemampuan/keterampilan melakukan sesuatu.

d. Untuk mengukur keberhasilan pembelajaran, guru harus meminta siswa melakukan aktivitas tertentu secara bermakna yang mencerminkan aktivitas di dunia nyata.

e. Assessment drives the curriculum; the teachers first determine the tasks that student will perform to demonstrate their mastery.

Selain hal-hal di atas, hal lain yang membedakan kedua jenis penilaian tersebut, jika dibuat secara pilah dikotomis, adalah berupa perbedaan antara: (i) memilih jawaban dan menunjukkan suatu aktivitas; menunjukkan penguasaan pengetahuan dan demonstrate proficiency by doing something; (iii) memanggil kembali atau rekognisi dan mengkonstruksi atau aplikasi; (iv) soal dan jawaban disusun guru dan siswa menyusun sendiri jawaban; dan (v) bukti tidak langsung dan bukti langsung (faktual).

Perbedaan di antara kedua model penilaian di atas sebenarnya tidak perlu dibesarbesarkan. Bagaimanapun juga, dalam kegiatan pembelajaran di sekolah, keduanya tetap saja sama-sama dibutuhkan. Kedua model itu memiliki keunggulannya masing-masing. Tagihan terhadap pengetahuan yang dimiliki pembelajar (proficiency) tidak dapat dikesampingkan begitu saja karena ituakan mendasari pembelajar untuk dapat berunjuk-kerja secara benar, dan penguasaan terhadap pengetahuan itu lebih tepat diukur dengan tes tradisional. Namur, penilaian tidak benar jika hanya berurusan dengan hal-hal seperti itu. Kedua model penilaian tersebut disarankan sama-sama dipergunakan untuk mengukur kompetensi yang sesuai, namun dengan penekanan pada penilaian otentik. Jadi, penggunaan kedua model penilaian itu bersifat saling melengkapi. Hal itu mirip dengan penilaian komunikatif dalam pembelajaran bahasa yang juga membenarkan adanya penilaian prakomunikatif sebelum pembelajar menguasai sistem bahasa target untuk dapat berkomunikasi dengan bahasa itu secara konkret.

\section{Manfaat Penggunaan Penilaian Otentik}

Mengapa penilaian otentik kini disarankan penggunaannya, apakah model itu berbeda dan menjanjikan hasil yang secara teoretis berbeda dengan model penilaian tradisional? Karena penilaian otentik menekankan capaian pembelajar untuk menunjukkan 
kinerja, doing something, kesiapan pembelajaran untuk berunjuk kerja selepas mengikuti kegiatan pembelajaran tentu lebih signifikan. Selain itu, ada beberapa manfaat lain penggunaan penilaian otentik, sebagaimana dikemukakan Mueller (2008), yaitu sebagai berikut.

Pertama, penggunaan penilaian otentik memungkinkan dilakukannya pengukuran secara langsung terhadap kinerja pembelajar sebagai indikator capain kompetensi yang dibelajarkan. Penilaian yang hanya mengukur capaian pengetahuan yang telah dikuasai pembelajar hanya bersifat tidak langsung. Tetapi, penilaian otentik menuntut pembelajar untuk berunjuk kerja dalam situasi yang konkret dan sekaligus bermakna yang secara otomatis juga mencerminkan penguasaan dan keterampilan keilmuannnya. Unjuk kerja tersebut bersifat langsung, langsung terkait dengan konteks situasi dunia nyata dan tampilannya juga dapatdiamati langsung. Hal itu lebih mencerminkan tingkat capaian pada bidang yang dipelajari.

Kedua, penilaian otentik memberi kesempatan pembelajar untuk mengonstruksikan hasil belajamya. Penilaian haruslah tidak sekadar meminta pembelajar mengulang apa yang telah dipelajari karena hal demikian hanyalah melatih mereka menghafal dan mengingat saja yang kurang bermakna. Dengan penilaian otentik pembelajar diminta untuk mengkonstruksikan apa yang telah diperoleh ketika mereka dihadapkan pada situasi konkret. Degan cara ini pembelajar akan menyeleksi dan menyusun jawaban berdasarkan pengetahuan yang dimiliki dan analisis situasi yang dilakukan agar jawabannya relevan dan bermakna.

Ketiga, penilaian otentik memungkinkan terintegrasikannya kegiatan pengajaran, belajar, dan penilaian menjadi satu paket kegiatan yang terpadu. Dalam pembelajaran tradisional, juga model penilaian tradisional, antara kegiatan pengajaran dan penilaian merupakan sesuatu yang terpisah, atau sengaja dipisahkan. Namun, tidak demikian halnya dengan model penilaian otentik. Ketiga hal tersebut, yaitu aktivitas guru membelajarkan, siswa belajar, dan guru menilai capaian hasil belajar pembelajar, merupakan satu rangkaian yang memang sengaja didesain demikian. Ketika guru membelajarkan suatu topik dan pembelajar aktif mempelajari, penilaiannya bukan semata berupa tagihan terhadap penguasaan topik itu, melainkan pembelajar juga diminta untuk berunjuk kerja mempraktikkannya dalam sebuah situasi konkret yang sengaja diciptakan. 
Keempat, penilaian otentik memberi kesempatan pembelajar untuk menampilkan hasil belajamya, unjuk kerjanya, dengan cara yang dianggap paling baik. Singkatnya, model ini memungkinkan pembelajar memilih sendiri cara, bentuk, atau tampilan yang menurutnya paling efektif. Hal itu berbeda dengan penilaian tradisional, misalnya bentuk tes pilihan ganda, yang hanya memberi satu cara untuk menjawab dan tidak menawarkan kemungkinan lain yang dapat dipilih. Jawaban pembelajar dengan model ini memang seragam, dan itu memudahkan kita mengolahnya, tetapi itu menutup kreativitas pembelajar untuk mengkreasikan jawaban atau kinerjanya. Padahal, unsur kreativitas atau kemampuan berkreasi merupakan hal esensial yang harus diusahakan ketercapaiannya dalam tujuan pembelajaran.

\section{Pengembangan Penilaian Otentik}

Semua rangkaian dalam lingkup kegiatan belajar mengajar hams direncanakan dengan baik agar dapat memberikan hasil dan dampak yang maksimal. Hal inilah antara lain yang kemudian mendorong intensifnya penerapan teknologi pendidikan dalam dunia pendidikan. Perencanaan yang baik juga harus diterapkan dalam kegiatan penilaian yang menjadi bagian integral dari kegiatan pembelajaran. Mueller (2008) mengemukakan sejumlah langkah yang perlu ditempuh dalam pengembangan penilaian otentik, yaitu yang meliputi (i) penentuan standar; (ii) penentuan tugas otentik; (iii) pembuatan kriteria; dan (iv) pembuatan rubrik.

a. Penentuan Standar

Standar dimaksudkan sebagai sebuah pernyataan tentang apa yang harus diketahui atau dapat dilakukan pembelajar. Di samping standar ada goal (tujuan umurn) dan objektif (tujuan khusus), dan standar berada di antara keduanya. Standar dapat diobservasi (observable) dan diukur (measurable) ketercapaiannya. Istilah umum yang dipakai di dunia pendidikan di Indonesia untuk standar adalah kompetensi sebagaimana terlihat pada KBK dan KTSP. Di kurikulum tersebut dikenal adanya istilah standar kompetensi lulusan dan korapetensi dasar. Standar kompetensi lulusan adalah kualifikasi kemampuan lulusan yang mencakup sikap, pengetahuan, dan keterampilan (PP No. 19 Tahun 2005: 2), sedang kompetensi dasar adalah kompetensi atau standar minimal yang harus tercapai atau dikuasai oleh pembelajar. 
b. Penentuan Tugas Otentik

Tugas otentik adalah tugas-tugas yang secara nyata dibebankan kepada pembelajar untuk mengukur pencapaian kompetensi yang dibelajarkan, baik ketika kegiatan pembelajaran masih berlangsung atau ketika sudah berakhir. Pengukuran hasil pencapaian kompetensi pembelajar yang secara realistik dilakukan di kelas dapat bersifat model tradisional atau otentik sekaligus tergantung kompetensi atau indikator yang akan diukur. Tugas otentik (authentic task) sering disinonimkan dengan penilaian otentik (authentic assessment) walau sebenarnya cakupan makna yang kedua lebih luas. Permasalahan yang segera muncul adalah tugas-tugas agar atau model-model pengukuran apayang dapat dikategorikan sebagai tugas atau penilaian otentik.

Semua kegiatan pengukuran pendidikan harus mengacu pada standar (standar kompetensi, kompetensi dasar) yang telah ditetapkan. Demikian pula halnya dengan pemberian tugas-tugas otentik. Pemilihan tugas-tugas tersebut pertama-tama haruslah merujuk pada kompetensi mana yang akan diukur pencapaiannya. Kedua, dan inilah yang khas penilaian otentik, pemilihan tugastugas itu harus mencerminkan keadaan atau kebutuhan yang sesungguhnya di dunia nyata. Jadi, dalam sebuah penilaian otentik masihterkandung dua hal sekaligus: sesuai dengan standar (kompetensi) dan relevan (bermakna) dengan kehidupan nyata. Dua hal tersebut haruslah menjadi acuan kita ketika membuat tugas-tugas otentik untuk mengukur pencapaian kompetensi pembelajaran kepada peserta

Dengan demikian, apa yang ditugaskan oleh guru kepada pembelajar dan yang dilakukan oleh pembelajar telah mencerrninkan kompetensi yang memang dibutuhkan dalam kehidupan nyata. Hal itu berarti ada keterkaitan antara dunia pendidikan di satu sisi dengan tuntutan kebutuhan kehidupan di dunia nyata di sisi lain. Misalnya, dalam pembelajaran bahasa, bahasa target apa saja, pasti terdapat standar kompetensi lulusan yang berkaitan dengan kemampuan menulis. Menulis dalam kaitan ini bukan sekedar menulis demi tulisan itu sendiri, melainkan menulis untuk menghasilkan karya tulis yang memang dibutuhkan di dunia nyata. Misalnya, menulis surat lamaran pekerjaan, surat penawaran produk, menulis artikel untuk media masa, dan lain-lain. Untuk itu, pembuatan tugas-tugas otentik dalam rangka penilaian otentik capaian hasil belajar peserta didik masih terkait dengan kemampuan menghasilkan karya tulis jenis-jenis tersebut. 


\section{c. Pembuatan Kriteria}

Jika standar (kompetensi, kompetensi dasar) merupakan arah dan acuan kompetensi pembelajaran yang dibelajarkan oleh pendidik dan sekaligus akan dicapai dalam oleh subjek didik, proses pembelajaran haruslah secara sadar diarahkan ke capaian kompetensi yang telah ditetapkan sebelumnya. Demikian pula halnya dengan penilaian yang dimaksudkan untuk mengukur kadar capaian kompetensi sebagai bukti hasil belajar. Untuk itu, diperlukan kriteria yang dapat menggambarkan capaian kompetensi yang dimaksud. Kriteria merupakan pernyataan yang menggambarkan tingkat capaian dan bukti-bukti nyata capaian belajar subjek belajar dengan kualitas tertentu yang diinginkan. Kriteria lazimnya juga telah dirumuskan sebelum pelaksanaan pembelajaran. Dalam kurikulum berbasis kompetensi kriteria lebih dikenal dengan sebutan indikator.

Dalam kegiatan pembelajaran, semua kompetensi yang dibelajarkan harus diukur kadar capaiannya oleh pembelajar. Jika dalam lingkup penilaian otentik harus melibatkan dua macam relevansi, yaitu sesuai dengan kompetensi dan bermakna dalam kehidupan nyata, kriteria atau indikator penilaian yang dikembangkan harus juga mengandung kedua tuntutan tersebut. Singkatnya, sebuah kriteria penilaian capaian hasil belajar harus cocok dengan kompetensi yang dibelajarkan dan sekaligus bermakna atau relevan dengan kehidupan nyata. Jumlah kriteria yang dibuat bersifat relatif, tetapi sebaiknya dibatasi, dan yang pasti kriteria harus mengungkap capaian hal-hal yang esensial dalam sebuah standar (kompetensi) karena hal itulah yang menjadi inti penguasaan terhadap kompetensi pembelajaran. Kita tidak mungkin menagih semua tugas yang dibelajarkan dan sekaligus dipelajari subjek didik.

Selain itu, pembuatan kriteria harus mengacu pada ketentuan-ketentuan yang selama ini dinyatakan baik, baik dalam arti efektif untuk keperluan penilaian hasil belajar. Ketentuan-ketentuan itu antara lain (i) harus dirumuskan secara jelas; (ii) singkat padat; (iii) dapat diukur, dan karenanya haruslah dipergunakan kata-kata kerja operasional; (iv) menunjuk pada tingkah laku basil belajar, apa yang mesti dilakukan dan bagaimana kualitas yang dituntut; dan (v) sebaiknya ditulis dalam bahasa yang dipahami oleh subjek didik. Perumusan kriteria yang jelas dan operasional akan mempermudah kita, para guru, untuk melakukan kegiatan penilaian. 


\section{d. Pembuatan Rubrik}

Penilaian otentik menggunakan pendekatan penilaian acuan kriteria (criterion referenced measures) untuk menentukan nilai capaian subjek didik. Dengan demikian, nilai seorang pembelajar ditentukan seberapa tinggi kinerja ditampilkannya secara nyata yang menunjukkan tingkat capaian kompetensi yang dibelajarkan. Untuk menentukan tinggi rendahnya skor kinerja yang dimaksud, haruslah dipergunakan alat skala untuk memberikan skorskor tiap kriteria yang telah ditentukan. Alat yang dimaksud disebut rubrik (rubric). Rubrik dapat dipahami sebagai sebuah skala penyekoran (scoring scale) yang dipergunakan untuk menilai kinerja subjek didik untuk tiap kriteriaterhadap tugastugas tertentu (Mueller, 2008).

Dalam sebuah rubrik terdapat dua hal pokok yang harus dibuat, yaitu kriteria dan tingkat capaian kinerja (level of performance) tiap kriteria. Kriteria berisi hal-hal esensial standar (kompetensi) yang ingin diukur tingkat capaian kinerjanya yang secara esensial dan konkret mewakili standar yang diukur capaiannya. Dengan membatasi kriteria pada hal-hal esensial, dapat dihindari banyaknya kriteria yang dibuat yang menyebabkan penilaian menjadi kurang praktis. Selain itu, kriteria haruslah dirumuskan atau dinyatakan (jadi: berupa pernyataan dan bukan kalimat) singkat padat, komunikatif, dengan bahasa yang gramatikal, dan benar-benar mencerminkan hal-hal esensial (dari standar/kompetensi) yang diukur. Dalam sebuah rubrik, kriteria mungkin saja atau boleh juga dilabeli dengan kata-kata tertentu yang lebih mencerminkan isi, misalnya dengan kata-kata: unsur yang dinilai.

Tingkat capaian kinerja, di pihak lain, umumnya ditunjukkan dalam angkaangka, dan yang lazim adalah 1-3 atau 1-5, besar kecilnya angka sekaligus menunjukkan tinggi rendahnya capaian. Tiap angka tersebut biasanya mempunyai deskripsi verbal yang diwakili, misalnya skor 1: tidak ada kinerja, sedang skor 5: kinerja sangat meyakinkan dan bermakna. Bunyi deskripsi verbal tersebut harus sesuai dengan kriteria yang akan diukur. Yang pasti terdapat banyak variasi dalam pembuatan rubrik, juga untuk kriteria dan angka tingkat capaian kinerja. Penilaian tingkat capaian kinerja seorang pembelajar dilakukan dengan menandai angka-angka yang sesuai. Rubrik lazimnya ditampilkan dalam tabel, kriteria ditempatkan di sebelah dan tingkat capaian di sebelah 
kanan tiap kriteria yang diukur capaiannya itu. Misalnya, untuk mengukur kinerja proses IPS seorang siswa, dibuatkan rubrik sebagai berikut.

Tabel 2

Contoh Rubrik Penilaian Aktivitas Proses IPS

\begin{tabular}{|c|c|c|c|c|c|}
\hline \multirow[t]{2}{*}{ No } & \multirow[t]{2}{*}{ Aspek yang Dinilai } & \multicolumn{3}{|c|}{$\begin{array}{c}\text { Tingkat Capaian } \\
\text { Kinerja }\end{array}$} & \multirow[t]{2}{*}{ Ket } \\
\hline & & 1 & 2 & 3 & \\
\hline 1 & Mengamati dan Menuliskan Hasil Pengamatan & & & & \\
\hline 2 & Mendiskusikan Hasil Pengamatan & & & & \\
\hline 3 & Menyusun Laporan Pengamatan & & & & \\
\hline 4 & Menyajikan Laporan Hasil Pengamatan & & & & \\
\hline
\end{tabular}

Rubrik dapat juga dibuat secara analitis (analytic rubrics) dan holistik (holistic rubrics). Rubrik analitis menunjuk pada rubrik yang mernberilcan penilaian tersendiri untuk tiap kriteria. lath, tiap criteria mempunyai nilai tersendiri. Pada umumnya, rubrik bersifat analitis. Contoh di atas juga merupakan rubrik analisis. Rubrik holistik, di pihak lain, adalah yang tidak memberikan penilaian capaian kinerja untuk tiap kriteria. Penilaian capaian kinerja diberikan secara menyeluruh untuk seluruh kriteria sekaligus. Misalnya berdasarkan rubrik di atas disusun pedoman penskoran sebagai berikut.

\section{Mengamati dan Menuliskan Hasil Pengamatan}

3 = Siswa mampu menuliskan 5 jenis alat transportasi berdasarkan klasifikasinya.

2 = Siswa mampu menuliskan 3-4 jenis alat transportasi berdasarkan klasifikasinya.

1 = Siswa mampu menuliskan 1-2 jenis alat transportasi berdasarkan klasifikasinya.

\section{Mendiskusikan Hasil Pengamatan}

3 = Siswa mampu menemukan 5 karakteristik alat transportasi berdasarkan klasifikasinya.

2= Siswa mampu menuliskan 3-4 karakteristikalat transportasi berdasarkan klasifikasinya.

1= Siswa mampu menuliskan 1-2 karakteristik alat transportasi berdasarkan klasifikasinya.

3. Menyusun Laporan Pengamatan

3 = Siswa mampu menuliskan 5 pendapatnya dalam diskusi.

$2=$ Siswa mampu menuliskan 3-4pendapatnya dalam diskusi.

1= Siswa mampu menuliskan 1-2pendapatnya dalam diskusi

\section{Menyajikan Laporan Hasil Pengamatan}

3 = Siswa menyajikan laporan, bertanya, dan menjawab pertanyaan saat diskusi kelas.

$2=$ Siswa bertanya dan atau menjawab pertanyaan saat diskusi kelas .

$1=$ Siswa pasif selama diskudi kelas. 
Perhitungan jumlah skor penilaian proses di atas adalah jumlah skor diperoleh siswa dibagi skor ideal dikalikan skala penilaian yang digunakan. Misalnya siswa A mendapat skor dari tiap indikator: 3, 2, 3, dan 2, skor totalnya adalah 10. Nilai akhirnya adalah (10:12) X100 =8,33.

\section{Penilaian Otentik dan Pendidikan Karakter}

Penilaian otentik merupakan sebuah bentuk penilaian yang mengukur kinerja nyata yang dimiliki siswa. Kinerja yang dimaksud adalah aktivitas dan hasil aktivitas yang diperoleh siswa selama proses pembelajaran. Berdasarkan pemahaman ini penilaian otentik pada prinsipnya mengukur aktivitas yang dilakukan oleh siswa selama proses pembelajaran berlangsung.

Bertemali dengan pendidikan karakter, pendidikan karakter bertujuan agar siswa mampu menjadi orang yang berkarakter mulia. Usaha pengembangan karakter ini harus dilakukan secara bekesinambungan dalam proses pembelajaran. Secara praktisnya, pembentukan dan pengembangna karakter ini bersifat integratif dengan aktivitas belajar yang dilakukan siswa. Oleh sebab itu, untuk mampu mengukur perkembangan karakter siswa diperlukan sebuah alat yang secara otomatis mampu mengukur aktivitas dan sekaligus menunjukkan karakter siswa. Alat itu adalah penilaian otentik. Guna memperjelas keterhubungan ini marilah kita simak penerapan praktisnya pada salah dua contoh pembelajaran berikut.

Seorang guru SD bermaksud mengajarkan konsep perkembangan alat transportasi. Tujuan pembelajarannya adalah siswa mampu menyebutkankan jenis, ciri, dan karakteristik alat tranportasi. Dalam proses pembelajarannya, guru tersebut telah merencanakan penerapan model kontekstual, sehingga disusunlah seperangkat RRP dengan langkah-langkah pebelajaran sebagai berikut. 
1. Kegiatan awal ( 10 menit )

a. Mengondisikan kelas agar siswa siap mengikuti pembelajaran

b. Apersepsi

Mengulas materi sebelumnya yaitu teknologi produksi dan komunikasi, kemudian menjelaskan bahwa kedua teknologi tersebut berkaitan erat dengan teknologi transportasi dan menanyakan pada siswa tentang alat transfortasi yang pernah digunakan.

c. Menjelaskan tujuan pembelajaran yang ingin dicapai

d. Menjelaskan prosedur pembelajaran yang akan dilakukan siswa.

2. Kegiatan inti ( 50 menit )

Eksplorasi

a. Siswa melakukan pengamatan terhadap gambar yang disediakan guru pada empat dinding kelas secara berkelompok (masing-masing kelompok satu gambar). (disiplin)

b. Siswa mencatat jenis-jenis alat transportasi yang ada di dalam gambar dalam Lembar Kerja Proses yang diterima dari guru. (teliti)

Elaborasi

c. Siswa mendiskusikan jenis-jenis alat transportasi dan karakteritiknya serta kegunaannya. (demoktratis/ tanggung jawab)

d. Siswa menyusun laporan hasil diskusi dan menunjuk perwakilan kelompok. (kreatif)

e. Siswa membacakan laporan diskusi tentang jenis teknologi transportasi diselingi tanya jawab. (tanggung jawab/ demokratis)

Konfirmasi

f. Siswa menyimak penjelasan guru tentang jenis dan karakteristik alat tranportasi. (rasa ingin tahu)

g. Siswa menjawab pertanyaan guru tentang kegunaan alat transportasi di sekitas lingkungannya. (peduli lingkungan)

3. Kegiatan akhir

a. Siswa dan guru menyimpulkan materi pembelajaran.

b. Siswa melaksanakan evaluasi.

c. Siswa dan guru merefleksi pembelajaran

d. Siswa mendapatkan tugas rumah untuk mencatatn alat-alat transportasi di lingkungannya berdasarkan jenis, karakteristik, dan kegunaanya..

Berdasarkan rancangan pembelajaran di atas, untuk mengukur kinerja/ aktivitas siswa selama pembelajaran guru menyusun penilaian otentik berbentuk penilaian kinerja. Dalam penilaiannya tersebut, ada beberapa aktivitas yang dilakukan siswa sekaligus menggambarkan karakter siswa. Aktivitas yang akan diukur adalah sebagai berikut.

1. Mengamati gambar dan membuat catatan hasil pengamatan.

2. Mendiskusikan karakteristik alat transportasi

3. Menyusun laporan hasil pengamatan

4. Melaporkan hasil diskusi

Atas dasar aktivitas tersebut selanjutnya disusun lembar kerja proses (LKP) sebagai berikut. 
Amati gambar yang terdapat pada dinding kelas. Berdasarkan pengamatan tersebut isilah peta konsep di bawah ini!

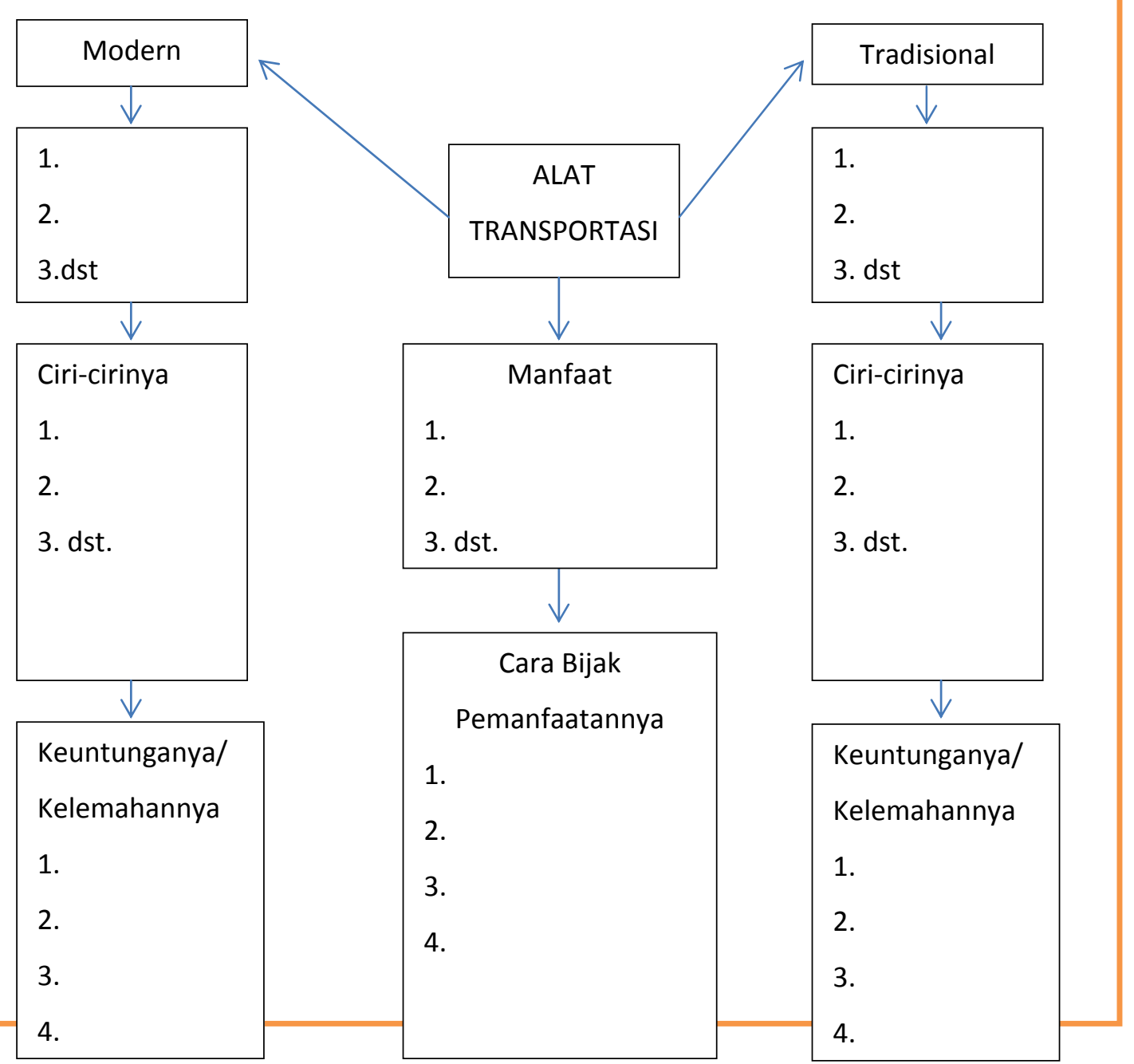


Berdasarkan LKP tersebut disusunlah rubrik penilaian yang mengukur kemampuan proses siswa sekaligus mengukur karakter siswa, misalnya sebagai berikut.

\section{Kemampuan mengamati dan Karakter Disiplin dan Teliti}

3 jika siswa mampu menuliskan 5 jenis alat transportasi berdasarkan klasifikasinya.

2 jika siswa mampu menuliskan 3-4 jenis alat transportasi berdasarkan klasifikasinya.

1 jika siswa mampu menuliskan 1-2 jenis alat transportasi berdasarkan klasifikasinya

Berdasarkan rubrik di atas, dapat kita tafsirkan jika siswa A mampu menuliskan 5 jenis alat transportasi berdasarkan klasifikasinya, siswa A tersebut mendapat nilai proses 3. Karena kemampuanya menuliskan 5 jenis alat transportasi berdasarkan klasifikasinya merupakan cermin nilai karakter disipilin dan teliti, siswa tersebut juga mendapatkan nilai 3 dalam penilaian pengembangkan karakter. Demikian seterusnya dalam seluruh aspek penilaian proses dan karakter.

\section{E. Penutup}

Pendidikan karakter hendanya disikapi secara bijak dalam pelaksanaanya. Salah satu wujud nyata kebijakan tersebut adalah menentukan cara paling logis dalam melaksanakan pendidikan karakter. Cara tersebut salah satunya adalah mengembangkan pembelajaran secara otentik sekaligus melaksanakan penilaian otentiktinya. Pemikiran ini didasari kosepsi bahwa pembelajaran adalah sejumlah aktivitas, dan melalui aktivitas inilah karakter bisa dibentuk. Bertemali dengan hal tersebut, dapat disimpulkan bahwa minimal ada dua langkah yang tepat dalam melaksanakan pendidikan karakter yaitu melaksanakan pembelajaran aktif dan melaksanakan penilaian otentik.

Penilaian otentik selain sebagai dasar penentuan aktivitas dan nilai karakter yang hendak dikembangkan, juga bisa digunakan untuk mengukur proses 
pembelajaran sekaligus mengukur karakter anak. Oleh sebab itu pengembangan model penilaian otentik sangat berpengaruh terhadap telaksananya pendidikan karakter.

\section{DAFTAR PUSTAKA}

Abidin, Y. 2011. "Model Penilaian Otentik dalam Pembelajaran Membaca Pemahaman: Sebuah Tawaran Konseptual" Disajikan dalam Seminar Nasional Asosiasi Pengajar Bahasa Indonesia. Bandung.

Brown, Douglas H. 2004. Language Assessment, Principle and Classroom Practices. San Francisco: Longman.

Genesse, Fred dan Upshur, John A. 1999. Classroom-Based Evaluation in Second Language Education. Cambridge: Cambridge University Press.

Kemendiknas. 2010. Pengembangan Pendidikan Budaya dan Karakter Bangsa. Jakarta: Balitbang-Kemendiknas.

Lynch, Brian K. 1996. Language Program Evaluation. Cambridge: Cambridge University Press.

Mahanal, Susriyati. 2005. Penerapan Portofolio sebagai Asesmen Otentik pada Pembelajaran IPA dengan Strategi Kontekstual bagi Siswa Kelas III SD Laboratorium Universitas Negeri Malang. Malang: Lembaga penelitian.

Marhaeni, A. A. I. N. (2005). Pengaruh Asesmen Portofolio dan Motivasi Berprestasi terhadap Kemampuan Menulis Bahasa Inggris (disertasi tak dipublikasikan), Jakarta: Universitas Negeri Jakarta.

Mueller, John. 2008. Authentic Assessment Toolbox. North Central Collegehttp:/ /www.noctrl.edu/,Naperville, hittp//jonathan.-mueller.faculty.noctrl.edu/toolbox /index.htm (Diunduh 27 Juni 2011).

Nitko A.J. (1996). Educational Assessment of Students, $2^{\text {nd }}$ Ed. Columbus Ohio : Prentice Hall.

Nurgiantoro, B. 2011. Penilaian Otentik. Yogyakarta: UGM Press.

O’Malley, J.M. \& Valdez Pierce, L. (1996). Authentic Assessment for English Language Learners. New York: Addison-Wesley Publishing Company.

Peraturan Pemerintah Republik Indonesia Nomor 19 Tahun 2005 tentang Standar Pendidikan Nasional.

Popham, W. James. 2008. Classroom Assessment, What Teachers Need to Know. Boston: Allyan and Bacon.

Rolheiser, C. \& Ross, J. A. (2005) Student Self-Evaluation: What Research Says and What Practice Shows. Internet download.

Salvia, J. \& Ysseldyke, J.E. (1996). Assessment. $6^{\text {th }}$ Edition. Boston: Houghton Mifflin Company.

Wyaatt III, R.L. \& Looper, S. (1999). So You Have to Have A Portfolio, a Teacher's Guide to Preparation and Presentation. California: Corwin Press Inc. 


\section{BIODATA}

Yunus Abidin adalah tenaga edukatif pada UPI Kampus Cibiru.Pembelajaran Bahasa Indonesia, Penilaian Otentik, dan Pendidikan Berbasis Karakter merupakan tiga bidang yang sedang digelutinya saat ini. 